\title{
The Literacy Habituation to Grow Early Childhood Language Skills Through Picture Story Books in Early Childhood Education
}

\author{
Linda Fasha Hidayat ${ }^{1}$, Asep Bayu Dani Nandiyanto,"*, Tedi Kurniawan³, Muhammad \\ Roil Bilad ${ }^{4}$ \\ ${ }^{1}$ Pendidikan Guru Pendidikan Anak Usia Dini, Universitas Pendidikan Indonesia, Bandung \\ ${ }^{2}$ Pendidikan Kimia, Universitas Pendidikan Indonesia, Bandung \\ ${ }^{3}$ Community College of Qatar, Qatar \\ ${ }^{4}$ Faculty of Integrated Technologies, University Brunei Darussalam, Brunei Darussalam \\ *Corresponding author: nandiyanto@upi.edu
}

\begin{abstract}
Abstrak: Literasi merupakan keterampilan berbahasa yang dimiliki seseorang dalam berkomunikasi. Pembiasaan literasi perlu dilakukan sejak dini karena akan membuat anak terbiasa dengan literasi yang juga akan mampu menumbuhkembangkan imajinasinya. Saat ini banyak pihak yang menerapkan literasi pada anak usia dini dengan proses yang tidak tepat, sebagian anak dituntut untuk bisa membaca dan menulis dengan metode yang menuntut anak untuk berpikir keras. Dengan menggunakan media buku cerita bergambar akan menumbuhkan kemampuan literasi anak. Dalam metode kuantitatif ini, penulis mengambil sampel dari beberapa anak dengan teknik pengumpulan data yaitu wawancara dan kuisioner. Hasil pendataan menyatakan bahwa delapan dari sepuluh anak berhasil mengikuti kebiasaan literasi yang penulis terapkan. Oleh karena itu, literasi sangat penting diterapkan pada anak usia dini agar anak dapat memiliki kemampuan berkomunikasi secara efektif yang dapat mengembangkan potensi dirinya dan berpartisipasi dalam kehidupan masyarakat di masa depan.
\end{abstract}

Kata kunci: Anak usia dini, buku cerita bergambar, kemampuan berbahasa, literasi

Abstract: Literacy is a language skill possessed by someone in communicating. Literacy habituation needs to be done from an early age because it will make children accustomed to literacy which will also be able to cultivate their imagination. At this time, many parties apply literacy to early childhood with an inappropriate process, some children are required to be able to read and write in a method that requires children to think hard. By using picture storybook media, it will foster children's literacy skills. In this quantitative method, the authors take samples from several children with observational data collection techniques, namely interviews and questionnaires. The results of data collection stated that eight out of ten children succeeded in following the literacy habits that the authors applied. Therefore, literacy is very important to be applied to early childhood so that children can have the ability to communicate effectively that can develop their potential and participate in community life in the future.

Keywords: Early childhood, language skills, literacy, picture story books 


\section{Introduction}

This literacy ability is the ability to read and write. This ability will later become a provision for children to be used in everyday life (Zati, Vidya dwi Amalia, 2018). Hasanah \& Deiniatur (2019: 12) argue that literacy is not just an elementary ability to read, write and count. Literacy in the modern sense includes language skills, arithmetic, interpreting images, computer literacy and various efforts to gain knowledge. Abidin in Marwiyati \& Hidayatulloh (2018: 67) McGee and Purcell-Gates mentions that literacy development contains two time periods, in detail starting from birth to age five and from age five to becoming an independent reader. Instilling a literacy culture is not easy, it requires a long process. This culture can be started from the family, school and community environment (Sumaryanti, 2018). According to Meliantina (2019: 124), in the implementation of the school literacy program, all teachers have their respective roles in relation to literacy activities. The process is fast but takes a lot of time.

Children who demonstrate good literacy skills from an early age are more likely to become successful readers (Chapman and Prochnow, 2006; Shanahan and Lonigan, 2013; Prioletta and Pyle, 2017). Storch and Whitehurst (2002) explain that phonological awareness, along with writing knowledge, has an impact on children's reading ability in PAUD. Prioletta and Pyle (2017: 405-406) explain about literacy practices for children, with the availability of reading and writing sources in the play environment, they can be integrated with games through writing, drawing and playing drama activities so that they can support children's literacy experiences concretely. This agrees with the results of Arsa's research (2019: 136) that early childhood literacy experiences occur through drawing activities, telling stories about experiences, counting, and reading. Furthermore, Elliott and Olliff (2008: 552) found that the importance of creating activities related to all domains of child development (physical, socio-emotional and cognitive) in a fun way with the aim of advancing the development of literacy skills that emerge from preschool age children.

The development of literacy in children is closely related to language or communication skills. Communication to fulfill the function of exchanging thoughts and feelings. Literacy is part of the development of children's language skills which is very important to be stimulated from an early age. Before children can read and write, through this literacy can provide experience to children about the concept of letter knowledge, understanding, vocabulary, writing and reading. 
The purpose of this study was to see to what extent children's language growth can be achieved in the literacy habituation program. If children have literacy experience, children will easily learn to read and write, so that it will have a good impact on better academics in the future.

\section{Method}

The method used to conduct this activity is a quantitative method. In this quantitative method, we took a sample of several children in PAUD Tunas Buana Subang with the data collection technique conducting direct observations and filling out questionnaires. This observation was carried out online using the whatsapp application and zoom meeting with 10 children who were accompanied by their parents and 2 teachers from the school. This activity was conducted using a pretest before the implementation of literacy habituation using picture storybook media, then after the literacy habituation treatment we were given another post-test to see how and what extent children's language development was stimulated.

\section{Result and Discussion}

This activity was conducted in a kindergarten. In the first stage, we conducted an interview with one of the teachers and then discussed the children's development and explained the program that would be applied to several children in the kindergarten. Then the teacher determines the children who will be used as activity samples and 10 people are selected with details of women as much as $70 \%$ and men as much as $30 \%$. A snapshot of this activity is shown in Figure 1.
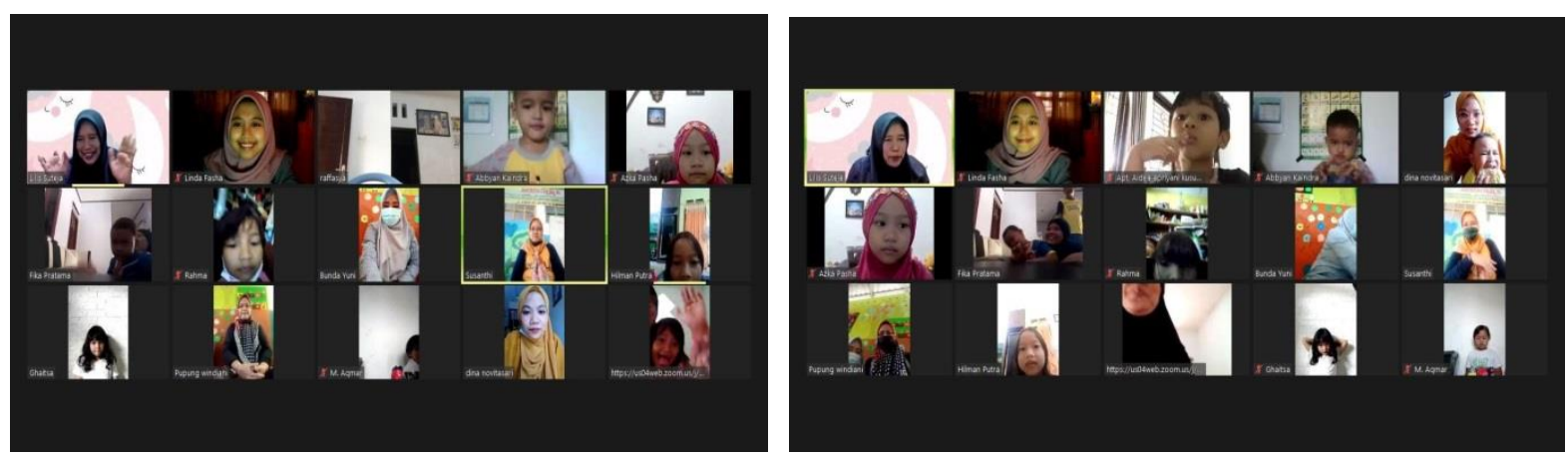

Figure 1. Online learning implementation

The pretest contains 10 questions with Yes or No answer choices. After that, we will provide treatment in the form of online learning which is carried out in a zoom meeting 
Jurnal Abdimas Kartika Wijayakusuma ISSN 2716-3512 (Online) ISSN 2721-0367 (Print)
This work is licensed under a Creative Commons Attribution-ShareAlike 4.0 International License. CC BY SA

application in which we had prepared several picture books to tell the children. After the treatment was given, we gave post-test questions with 10 questions that were the same as the pretest with the aim of knowing the extent of children's understanding and language growth.

Table 1 summarizes the pretest and post-test results.

Table.1 Pretest and Posttest Results

\begin{tabular}{|c|c|c|c|c|}
\hline No. & About & Pretest & Posttest & Gain \\
\hline 1. & $\begin{array}{l}\text { Has the child ever been learn about } \\
\text { literacy in school? }\end{array}$ & $100 \%$ & $100 \%$ & $0 \%$ \\
\hline 2. & $\begin{array}{l}\text { Has the child ever done literacy } \\
\text { habituation at school on a regular basis? }\end{array}$ & $50 \%$ & $90 \%$ & $40 \%$ \\
\hline 3. & $\begin{array}{l}\text { Has the child ever done literacy habits } \\
\text { at home on a regular basis? }\end{array}$ & $70 \%$ & $100 \%$ & $30 \%$ \\
\hline 4. & $\begin{array}{l}\text { Has the child ever listened to a story } \\
\text { from a picture book? }\end{array}$ & $100 \%$ & $100 \%$ & $0 \%$ \\
\hline 5. & $\begin{array}{l}\text { Can the child understand the story of } \\
\text { the picture book? }\end{array}$ & $70 \%$ & $100 \%$ & $30 \%$ \\
\hline 6. & $\begin{array}{l}\text { Can the child retell the contents of the } \\
\text { storybook? }\end{array}$ & $40 \%$ & $90 \%$ & $50 \%$ \\
\hline 7. & $\begin{array}{l}\text { Has the child ever listened to a picture } \\
\text { book story through an online } \\
\text { application? }\end{array}$ & $30 \%$ & $100 \%$ & $70 \%$ \\
\hline 8. & $\begin{array}{l}\text { Can children understand if only explain } \\
\text { through a screen or also called online } \\
\text { learning? }\end{array}$ & $30 \%$ & $80 \%$ & $50 \%$ \\
\hline 9. & $\begin{array}{l}\text { Can the child retell it during online } \\
\text { learning? }\end{array}$ & $20 \%$ & $80 \%$ & $60 \%$ \\
\hline 10. & $\begin{array}{l}\text { Does the child have an interest in } \\
\text { listening to stories from picture books? }\end{array}$ & $40 \%$ & $90 \%$ & $50 \%$ \\
\hline
\end{tabular}

The results show several discussion points:

(i) The first question did not increase from pretest to posttest because the child had studied and was explained about literacy at school.

(ii) The second question there was a $40 \%$ increase because at the time of the pretest the school had not implemented literacy habituation but after being given socialization the school began to implement it routinely

(iii) The third question there is a $30 \%$ increase due to the increasing awareness of parents about the importance of literacy 
(iv) There is no improvement in the fourth question because at school they have heard stories from picture books

(v) The fifth question there is a $30 \%$ increase because the way the teacher delivers to children is further improved so that children understand easily

(vi) The sixth question has a 50\% increase because the teacher also improves the delivery method so that children are not shy and dare to express their opinions

(vii) The seventh question has a $70 \%$ increase because the children still rarely have meetings through zoom meetings.

(viii) The eighth question has a 50\% increase because we delivery in the zoom meeting attracts children's attention

(ix) The ninth question has a $60 \%$ increase because in its delivery we frees children to express opinions as they please

(x) The tenth question has a 50\% increase because children who were previously not interested in hearing stories through picture books are interested in hearing them again

Table 1 shows that literacy habituation to develop children's language skills through picture story books when given a pretest is $55 \%$. However, after being given treatment in the form of habituation of literacy, it increased to $93 \%$. Based on these results, it can be concluded that there has been an increase in literacy habituation through picture story books by $38 \%$. This increase is due to the way delivery to children is more varied so that it attracts children's interest.

\section{Conclusion}

Based on the results of the study above, it is stated that literacy habits need to be done from an early age. The results of this study showed literacy habits that children did as much as $55 \%$, seen in the process of giving the pretest and then growing rapidly to $93 \%$ in the posttest. Therefore, habituation of literacy is important from an early age because it will help stimulate development and grow children's language skills in communicating with people around them so that later children will be brave to develop their language skills.

\section{Acknowledgements}

We acknowledged Bangdos, Universitas Pendidikan Indonesia. We thank to Lilis Suteja, S.Pd. from PAUD Tunas Buana Subang. This study is a part of Community Service 
Program Tematik Literasi 2021 from group 21 Lembaga Penelitian dan Pengabdian Masyarakat (LPPM), Universitas Pendidikan Indonesia. We also thank to Kantor Jurnal and Publikasi, Directorate of International Affairs, Universitas Pendidikan Indonesia. We thank to Nissa Nur Azizah, Dwi Fitria Al Husaeni, Muktiarni, S.Pd., M.Pd., Rina Maryanti, S.Pd., M.Pd., and Asri Wibawa Sakti, M.Pd.

\section{References}

Arsa, D. 2019. Literasi awal pada anak usia dini suku anak dalam dharmasyara. Jurnal Obsesi : Jurnal Pendidikan Anak Usia Dini, 3(1), 127-136.

Chapman, J., \& Prochnow J. 2006. Literate cultural capital at school entry predicts later reading achievement : A seven year longitudinal study. New Zealand Journal of Educational Studies, 41(2), 183-204.

Elliott, E. M., \& Olliff, C. B. 2008. Developmentally appropriate emergent literacy activities for young children: Adapting the early literacy and learning model. Early Childhood Education Journal, 35(6), 551-556.

Hasanah. U., \& Deiniatur. M. 2019. Membangun budaya membaca pada anak usia dini di era digital, At-Tajdid: Jurnal Pendidikan dan Pemikiran Islam, 3(01), 10-24.

Marwiyati, S., \& Hidayatulloh, M,A. 2018. Peran "cakruk baca bergerak" dalam pengembangan literasi anak usia dini. Awlady: Jurnal Pendidikan Anak, 4(2), 61-77.

Meliantina. M. 2019. Menerapkan budaya literasi guru sekolah dalam upaya meningkatkan pendidikan di era industri 4.0. Murobbi: Jurnal Ilmu Pendidikan, 3(2), 120-139.

Prioletta, J., \& Pyle, A. 2017. Play and gender in Ontario kindergarten classrooms: implications for literacy learning. International Journal of Early Years Education, 25(4), 393-408.

Stroch, S. A., \& Whitehurst, G. J. (2002). Oral Language and code-related precursors to reading : Evidence from a longitudinal structural model. Developmental Psychology, 38(6), 934-947.

Sumaryanti, L. 2018. Membudayakan literasi pada anak usia dini dengan metode mendongeng. Al-Asasiyya: Journal of Basic Education,3(1), 117-125.

Zati,V. D. A. 2018. Upaya untuk meningkatkan minat literasi anak usia dini. Jurnal Bunga Rampai Usia Emas, 4(1), 18-21. 